\title{
Phenotypic detection of metallo- $\beta$-lactamase (MBL) and AmpC enzymes among abattoir isolates of Escherichia coli and Klebsiella species in Abakaliki, Nigeria
}

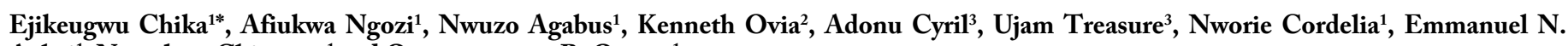
Agbai $^{1}$, Nwankwo Chinonso ${ }^{1}$ and Onwuenwunor B. Omaye ${ }^{1}$

${ }^{1}$ Department of Applied Microbiology, Faculty of Science, Ebonyi State University, Abakaliki, P.M.B 053, Ebonyi State, Nigeria

${ }^{2}$ Department of Biological Sciences, Evangel University, Akaeze, Ebonyi State, Nigeria

${ }^{3}$ Department of Pharmaceutical Microbiology and Biotechnology, Faculty of Pharmaceutical Sciences, Nnamdi Azikiwe University, Awka, P.M.B 5025, Anambra State, Nigeria

\begin{abstract}
The surveillance of antibiotic resistance and antibiotic usage in livestock and other agricultural practices is still relatively poor in Nigeria; and this allow drug resistant bacteria to emerge and spread in the community almost undetected. Bacteria that produce metallo- $\beta$-lactamases (MBLs) and AmpC enzymes are notably resistant to the carbapenems and cephamycins respectively. And these antibiotics are important antimicrobial agents used clinically for the treatment of infectious diseases. In this study, the frequency of MBL- and AmpC-producing Klebsiella species and Escherichia coli isolates was phenotypically investigated. A total of 50 anal swab samples were bacteriologically analyzed for the selective isolation of Klebsiella species and $E$. coli isolates which were identified by standard microbiology techniques. Antimicrobial susceptibility testing was carried out using the modified Kirby-Bauer disk diffusion technique. The production of MBLs and AmpC enzymes was phenotypically detected using Hodges (Cloverleaf) test and ceftazidime-imipenem antagonism test (CIAT) respectively. The multidrug resistant nature of the MBLand AmpC-producing Klebsiella species and E. coli isolates was calculated using the multiple antibiotic resistance index (MARI) formular. A total of 5 E. coli isolates and 12 isolates of Klebsiella species were bacteriologically recovered from the anal swab samples. The Klebsiella species were resistant or intermediately resistant to cefoxitin (66.7\%), ceftazidime (58.3\%), cloxacillin (100\%), ertapenem (83.3\%), amikacin (16.7\%) and ofloxacin (16.7\%). E. coli isolates were also found to be resistant to cefoxitin (40\%), ceftazidime (40\%), cloxacillin (80\%) and ofloxacin (20\%). MBL was phenotypically detected in one (1) isolate of $E$. coli while AmpC enzyme production was detected in 9 isolates of Klebsiella species phenotypically. On average, the MBL-producing E. coli isolate and AmpC-producing Klebsiella species were multiply resistant to 7 antibiotics. This study has presumptively shown that bacteria from abattoir origin including Klebsiella species and $E$. coli isolates are notable $\mathrm{MBL}$ and AmpC enzyme producers, and they are multidrug resistant in nature. The use of antibiotics in agriculture and animal husbandry is a major driving force in the emergence and spread of resistant bacteria in the non-hospital environment. This should be discouraged at all levels to preserve the efficacy of available antibiotics especially in this environment where the detection of MBL- and AmpC-producing bacteria from clinical and non-clinical samples is still pitiable.
\end{abstract}

\section{Introduction}

Food-producing animals habouring multidrug resistance genes together with genes that mediate the production of some high-profile antibiotichydrolyzing enzymessuch as metallo-beta-lactamases(MBLs), extended spectrum beta-lactamases (ESBLs) and AmpC enzymes possess health risks to the human population particularly due to their potential contribution to the spread of drug resistant microorganisms in the community. And one of the biggest current challenges facing the health sector across the globe especially in the area of infection control and prevention is in the adequate containment of multidrug resistant Gram-negative organisms (MDRGNOs) such as Escherichia coli and Klebsiella species which are known to be notable for their antibiotic resistance prowess. The recurrent and irrational use of antibiotics in animal husbandry allows bacteria to develop and acquire drug resistant genes over time through selective pressure. This phenomenon accounts for the singular reason there is for the emergence and dissemination of drug resistant bacteria in the community especially in non-hospital environment [1]. Antibiotic resistant bacteria pose a significant health problem that could be degenerated through the continued irrational use of antibiotics [2]. The increase in the rates of antibiotic resistance is becoming a major cause for concern in isolates of the Enterobacteriaceae family [3]. Metallo- $\beta$-lactamases (MBLs) are group of $\beta$-lactamases that hydrolyze carbapenems, and have potent but variable enzymatic activity against other beta-lactam antibiotics except the monobactams $[4,5]$. MBLs, which are a type of carbapenemases, are an emerging public health problem among clinically important Gram negative organisms and bacteria isolated from non-clinical sources [6,7]. The presence of MBL-producing bacteria in the hospital and non-hospital environment puts the use of the carbapenems under threat [6,8-11]. AmpC enzymes are cephalosporinases encoded on the chromosomes of many Enterobacteriaceae and a few other bacteria where they mediate resistance to cephalothin, cefazolin, cefoxitin and most penicillin [12]. These enzymes are active on cephamycins such as cefoxitin; and they

Correspondence to: Ejikeugwu Chika, Ph.D., Department of Applied Microbiology, Faculty of Science, Ebonyi State University, Abakaliki, P.M.B 053, Ebonyi State, Nigeria, Tel: 2348097684562; E-mail: ejikeugwu_chika@yahoo.com

Key words: antimicrobial resistance, antimicrobial resistance, multidrug resistance, Metallo- $\beta$-Lactamases, AmpC enzymes, abattoir, Nigeria

Received: December 29, 2017; Accepted: January 2, 2018; Published: January 25,2018 
are encoded by bacterial chromosomes and plasmids in Gram negative bacilli. According to Jacoby [13], AmpC enzyme production in most Enterobacteriaceae is low but the hyper-production of AmpC enzymes in these organisms is usually induced by the exposure of the bacteria to beta-lactam drugs. The long-term and undue use of antibiotics in livestock, poultry and other agricultural activities selects for drug resistance in bacteria $[1,13,14]$. Enterobacteriaceae producing AmpC beta-lactamases have become a major therapeutic challenge; and their detection is of significant clinical relevance since AmpC producers may appear susceptible to expanded-spectrum cephalosporins when initially tested $[6,13,15]$. This may lead to inappropriate antimicrobial regimens and therapeutic failure since organisms expressing AmpC beta-lactamase are resistant to the antimicrobial actions of these drugs. The plethora of reports on MBL- and AmpC-producing bacteria from different geographical locations calls for need to always be on the lookout for these multidrug resistance enzymes $[1,7,8,15,16]$. In this study, the occurrence of MBL and AmpC-producing Klebsiella species and E. coli was phenotypically characterized.

\section{Materials and methods}

\section{Collection and processing of samples}

Fifty (50) anal swab samples were collected from the anal region of cows from a local abattoir in Abakaliki metropolis, Ebonyi State, Nigeria using sterile swab sticks soaked in normal saline. Each of the swab sticks was returned to their respective containers and labeled. All samples were transported to the Microbiology Laboratory Unit of Ebonyi State University, Abakaliki within one hour of collection for bacteriological analysis. Each of the collected samples was inserted into $5 \mathrm{ml}$ of freshly prepared nutrient broth (Oxoid, UK) and the tubes were loosely covered with cotton wool, and incubated at $30^{\circ} \mathrm{C}$ for 18 $24 \mathrm{~h}$. Bacterial growth was identified by the presence of turbidity or cloudiness in the broth culture after incubation [17].

\section{Isolation and identification of Escherichia coli and Klebsiella species}

A loopful of the turbid solution from the overnight broth culture was plated aseptically onto MacConkey agar (MAC) and eosin methylene blue (EMB) agar (Oxoid, UK) plates, and these were incubated at $30^{\circ} \mathrm{C}$ for $18-24 \mathrm{~h}$. Suspect colonies of E. coli and Klebsiella species were subcultured onto freshly prepared MAC and EMB agar plates for the isolation of pure cultures of E. coli and Klebsiella species. E. coli produces colonies with metallic green sheen on EMB agar and lactose-fermenting colonies on MAC; and Klebsiella species produce small, circular, elevated and mucoid colony on MAC and non-metallic green sheen mucoid colonies on EMB agar [17].

\section{Antimicrobial susceptibility testing}

This was performed using seven (7) different single antibiotic disks comprising: amikacin (AK, $30 \mu \mathrm{g}$ ), cefoxitin (FOX, $30 \mu \mathrm{g}$ ), cloxacillin (OB, $10 \mu \mathrm{g})$, ceftazidime (CAZ, $30 \mu \mathrm{g})$, ofloxacin (OFX, 5 $\mu \mathrm{g}$ ), ertapenem (ETP, $10 \mu \mathrm{g}$ ) and imipenem (IPM, $10 \mu \mathrm{g}$ ) as per the guidelines of the Clinical and Laboratory Standard Institute (CLSI). All antibiotic disks were in the single disk format, and they were procured from Oxoid limited (Oxoid, UK). The antimicrobial susceptibility testing was performed on Mueller-Hinton $(\mathrm{MH})$ agar plates (Oxoid, UK) using the modified Kirby-Bauer disk diffusion technique as was previously described $[18,19]$.

\section{Screening test for MBL production}

All bacterial isolates were phenotypically screened for the production of MBL enzymes by the Kirby-Bauer disk diffusion technique using imipenem (IPM, $10 \mu \mathrm{g}$ ), meropenem (MEM, $10 \mu \mathrm{g}$ ) and ertapenem (ETP, $10 \mu \mathrm{g}$ ) [Oxoid, UK] as was previously described $[4,19,20]$. Isolates showing inhibition zone diameter (IZD) of $\leq 23 \mathrm{~mm}$ were considered and suspected to produce MBL phenotypically.

\section{Phenotypic confirmation of MBL production}

The Hodges (Cloverleaf) test was used to phenotypically confirm MBL production in the bacterial isolates. This was performed by aseptically swabbing Mueller-Hinton ( $\mathrm{MH})$ agar plates with Escherichia coli ATCC 25922 strain. The inoculated MH agar plates were allowed for about $5 \mathrm{~min}$; and imipenem $(10 \mu \mathrm{g})$ disk was aseptically placed at the center of the $\mathrm{MH}$ agar plates. The test bacteria (adjusted to $0.5 \mathrm{McF}$ arland turbidity standards) were heavily streaked from the imipenem $(10 \mu \mathrm{g})$ disk to the edge of the $\mathrm{MH}$ agar plates. Susceptibility plates were incubated for $18-24 \mathrm{hrs}$ at $30^{\circ} \mathrm{C}$. The plates were macroscopically observed for indentation, and the growth of the test bacteria towards the imipenem $(10 \mu \mathrm{g})$ susceptibility disk. Presence of indentation and growth of test bacteria towards the carbapenem disk is indicative of metallo- $\beta$-lactamase (MBL) production phenotypically $[4,20]$.

\section{Screening test for AmpC enzyme production}

Bacterial strains that produce AmpC beta-lactamase enzymes are resistant to the cephamycins but susceptible to the fourth-generation cephalosporin, cefepime $[18,21]$. The susceptibility of the test isolates to cefoxitin disk $(30 \mu \mathrm{g})$ was used as the primary screening test to screen all the isolates for possible production of AmpC enzymes. AmpC enzyme production was suspected in those test isolates that showed reduced susceptibility to cefoxitin disk as per the breakpoints recommended by the CLSI $[18,19]$. Test isolates showing inhibition zone diameter (IZD) $<18 \mathrm{~mm}$ were suspected for the production of AmpC beta-lactamase enzyme.

\section{Detection of AmpC enzyme production}

AmpC enzyme production was phenotypically confirmed by the ceftazidime-imipenem antagonism test (CIAT) using ceftazidime (30 $\mu \mathrm{g})$, cefoxitin $(30 \mu \mathrm{g})$ and imipenem $(10 \mu \mathrm{g})$ disk. Ceftazidime disc and imipenem disk were placed at a distance of $20 \mathrm{~mm}$ apart on $\mathrm{MH}$ agar plate previously inoculated with a suspension of the test bacteria (adjusted to $0.5 \mathrm{McF}$ arland turbidity standards). Cefoxitin disk (30 $\mu \mathrm{g})$ was also placed at a distance of $20 \mathrm{~mm}$ from the ceftazidime disk for comparison. The entire susceptibility test plates were incubated at $30^{\circ} \mathrm{C}$ for $18-24 \mathrm{~h}$. Antagonism indicated by a visible reduction in the inhibition zone around the ceftazidime disk adjacent to the imipenem or cefoxitin disk was inferred as a positive inducible AmpC betalactamase production [1].

\section{Determination of Multiple Antibiotic Resistance Index (MARI)}

Multiple antibiotic resistance index (MARI) was calculated to determine the multiple antibiotic resistance profile of the isolated Klebsiella species and E. coli isolates that were positive for MBL and AmpC enzyme production. This was done according to the method of Akinjogunla and Enabulele [22]. MARI was calculated using the formular: MARI $=\mathbf{a} / \mathbf{b}$; where ' $\mathbf{a}$ ' represents the number of antibiotics which the resistant bacteria was resistant to; and 'b' represents the total number of antibiotics to which the resistant bacteria has been evaluated for.

\section{Results}

In this study, a total of 50 anal swab samples were bacteriologically analyzed for the selective isolation of Escherichia coli and Klebsiella 
Chika E(2018) Phenotypic detection of metallo-ß-lactamase (MBL) and AmpC enzymes among abattoir isolates of Escherichia coli and Klebsiella species in Abakaliki, Nigeria

species isolates. Table 1 shows the rate of isolation of Klebsiella species and $E$. coli isolates from the anal/rectal swab samples, as well as their Gram reaction, biochemical reaction and colonial features on culture media.

The result of the antimicrobial susceptibility pattern of the isolated Klebsiella species is shown in Table 2. The Klebsiella species were resistant or intermediately resistant to cefoxitin $(66.7 \%)$, ceftazidime (58.3\%), and (83.3\%). None of the isolates of Klebsiella species were susceptible to cloxacillin (100\%). Table 3 shows the result of the antimicrobial susceptibility profile of the $5 \mathrm{E}$. coli isolates bacteriologically recovered on this study from the anal swab samples. The antimicrobial susceptibility test revealed that the $5(100 \%)$ isolates of $E$. coli were completely susceptible to imipenem (IPM), ertapenem (ETP) and amikacin (AK). However, $3(60 \%)$ isolates of the E. coli were susceptible to cefoxitin (FOX) and ceftazidime while only $1(20 \%)$ isolate was susceptible to cloxacillin (OB).

Table 4 shows the prevalence of Klebsiella species and E. coli isolates that are positive for metallo- $\beta$-lactamase (MBL) production and AmpC enzymes in this study. In this study, only one (1) isolate of E. coli was phenotypically confirmed to produce MBL by the Hodges (Cloverleaf) test while none of the Klebsiella species isolates produced MBL phenotypically. AmpC enzyme production was phenotypically confirmed in 9 isolates of Klebsiella species by the ceftazidimeimipenem antagonism test (CIAT) method used in thus study. None of the E. coli isolates produced AmpC enzyme (Table 4). Table 5 shows

Table 1. Isolation of Escherichia coli and Klebsiella species

\begin{tabular}{|c|c|c|c|c|c|}
\hline Bacteria & $\begin{array}{c}\text { Sample } \\
\text { (n) }\end{array}$ & $\begin{array}{c}\text { Number } \\
\mathbf{( \% )}\end{array}$ & $\begin{array}{c}\text { Morphological } \\
\text { appearance }\end{array}$ & $\begin{array}{c}\text { Gram } \\
\text { reaction }\end{array}$ & $\begin{array}{c}\text { Biochemical } \\
\text { reaction }\end{array}$ \\
\hline $\begin{array}{c}\text { Escherichia } \\
\text { coli }\end{array}$ & $\begin{array}{c}\text { Anal } \\
\text { swabs } \\
(25)\end{array}$ & 5 & $\begin{array}{c}\text { Non-mucoid pinkish colonies } \\
\text { on MAC; metallic green sheen } \\
\text { colonies on EMB }\end{array}$ & $\begin{array}{c}\text { Gram } \\
\text { negative }\end{array}$ & $\begin{array}{c}\text { Indole } \\
\text { positive } \\
\text { MR positive }\end{array}$ \\
\hline $\begin{array}{c}\text { Klebsiella } \\
\text { species }\end{array}$ & $\begin{array}{c}\text { Anal } \\
\text { swabs } \\
(25)\end{array}$ & 12 & $\begin{array}{c}\text { Mucoid colonies on MAC; } \\
\text { non-metallic green sheen } \\
\text { colonies on EMB }\end{array}$ & $\begin{array}{c}\text { Gram } \\
\text { negative }\end{array}$ & $\begin{array}{c}\text { Citrate } \\
\text { positive } \\
\text { Urease } \\
\text { positive }\end{array}$ \\
\hline
\end{tabular}

n-Number; \%-Percentage; EMB-Eosin methylene blue; MAC-MacConkey; MR-Methyl red

Table 2. Percentage antimicrobial susceptibility profile of 12 isolates of Klebsiella species

\begin{tabular}{|c|c|c|}
\hline Antibiotics & \% Resistant & \% Susceptible \\
\hline IPM $(10 \mu \mathrm{g})$ & 0 & 100 \\
\hline FOX $(30 \mu \mathrm{g})$ & 66.7 & 33.3 \\
\hline AK $(10 \mu \mathrm{g})$ & 16.7 & 83.3 \\
\hline OFX $(10 \mu \mathrm{g})$ & 16.7 & 83.3 \\
\hline CAZ $(30 \mu \mathrm{g})$ & 58.3 & 41.7 \\
\hline OB $(200 \mu \mathrm{g})$ & 100 & 0 \\
\hline ETP $(10 \mu \mathrm{g})$ & 83.3 & 16.7 \\
\hline
\end{tabular}

FOX-Cefoxitin; IPM-Imipenem; CAZ-Ceftazidime; ETP-Ertapenem; OFX-Ofloxacin; AK-Amikacin; OB-Cloxacillin

Table 3. Percentage antimicrobial susceptibility profile of 5 isolates of $E$. coli

\begin{tabular}{|c|c|c|}
\hline Antibiotics $(\boldsymbol{\mu g})$ & $\begin{array}{c}\text { Susceptible } \\
\mathbf{n}(\mathbf{\%})\end{array}$ & $\begin{array}{c}\text { Resistant } \\
\mathbf{n}(\%)\end{array}$ \\
\hline IPM (10) & $5(100)$ & $0(0)$ \\
\hline ETP (10) & $5(100)$ & $0(0)$ \\
\hline FOX (30) & $3(60)$ & $2(40)$ \\
\hline CAZ (30) & $3(60)$ & $2(40)$ \\
\hline OB (200) & $1(20)$ & $4(80)$ \\
\hline OFX (10) & $4(80)$ & $1(20)$ \\
\hline AK (10) & $5(100)$ & $0(0)$ \\
\hline
\end{tabular}

IPM-Imipenem; ETP-Ertapenem; FOX-Cefoxitin; CAZ-Ceftazidime; OB-Cloxacillin; OFX-Ofloxacin; AK-Amikacin
Table 4. Frequency of MBL and AmpC positive Klebsiella species and E. coli isolates

\begin{tabular}{|c|c|c|}
\hline $\begin{array}{c}\text { Resistance } \\
\text { mechanism }\end{array}$ & Klebsiella species & Escherichia coli \\
\hline MBL & Nil & 1 \\
\hline AmpC & 9 & Nil \\
\hline
\end{tabular}

MBL-Metallo- $\beta$-lactamase

Table 5. Result of multiple antibiotic resistance index

\begin{tabular}{|c|c|}
\hline Isolate no. & MARI \\
\hline $\mathrm{E} 4$ & 0.3 \\
\hline $\mathrm{K} 2$ & 0.1 \\
\hline $\mathrm{K} 3$ & 0.6 \\
\hline $\mathrm{K} 4$ & 0.6 \\
\hline $\mathrm{K} 9$ & 0.4 \\
\hline $\mathrm{K} 10$ & 0.7 \\
\hline $\mathrm{K} 11$ & 0.6 \\
\hline $\mathrm{K} 13$ & 0.4 \\
\hline $\mathrm{K} 17$ & 0.6 \\
\hline $\mathrm{K} 23$ & 0.6 \\
\hline
\end{tabular}

E-Escherichia coli; K-Klebsiella

the result of the multiple antibiotic resistance index of the E. coli and Klebsiella species that produced MBL and AmpC enzymes respectively.

\section{Discussion}

Metallo- $\beta$-lactamase (MBL) and AmpC enzyme production in Gram negative bacteria is one of the major resistance mechanisms that allow bacterial isolates including members of Enterobacteriaceae and other non-enteric bacteria to resist the antimicrobial onslaught of some available potent antimicrobial agents. This mechanism of resistance has tremendous public health implications as they limit treatment options for some bacterial-related infections caused by MBL- and AmpCproducing bacteria. In this study, the occurrence of metallo- $\beta$-lactamase (MBL) and AmpC-producing Escherichia coli and Klebsiella species of abattoir origin was bacteriologically and phenotypically investigated. Klebsiella species and E. coli was appreciably isolated from the anal/ rectal swabs of cows that were used in this study. The rate of isolation of Klebsiella species and E. coli in this study does not correspond to our earlier report and that of others in which Klebsiella species and $E$. coli were recovered at a high rate from both clinical and non-clinical sources $[16,18,23]$. The result obtained from the susceptibility studies showed that $E$. coli exhibited the highest susceptibility to imipenem $(100 \%)$, ertapenem $(100 \%)$ and amikacin (100\%). More than $50 \%$ of the E. coli isolates were resistant to cloxacillin. All the Klebsiella isolates were particularly resistant to cloxacillin (100\%), ertapenem $(83 \%)$, cefoxitin (67\%) and ceftazidime (58\%). Most of the Klebsiella isolates were susceptible to some of the antibiotics such as imipenem $(100 \%)$, amikacin (83\%) and ofloxacin (83\%). The high level of resistance of the Klebsiella species and E. coli isolates used in this study to some commonly available antibiotics correspond to our previous reports and that of others in which E. coli and Klebsiella species were found to be highly resistant $[4,18,24]$. The resistance profile of the Klebsiella species and $E$. coli isolates recovered in this study connote to the usage of antibiotics in animals as growth promoting agents; and this practice contributes a great deal to the emergence and spread of resistant bacteria in the community [25]. In this study, MBL was phenotypically confirmed in one (1) isolate of E. coli while AmpC enzymes were detected in 9 isolates of Klebsiella species. The detection of MBL in the E. coli isolates was only phenotypically confirmed in one (1) isolate of E. coli, and this is very low when compared to our previous report and that of others on the frequency of MBL-producing Enterobacteriaceae 

Nigeria

from both community and hospital samples [1,3-5]. Our result on the prevalence of MBL- and AmpC-producing bacteria does not correspond to previous study in which E. coli and Klebsiella species that produced MBL and AmpC enzymes was reported at a higher rate [1,15,23,26,27]. The MBL-producing E. coli isolate and AmpC-producing Klebsiella species were multiply resistant to 7 antibiotics. This shows that MBLand AmpC-producing bacteria are multidrug resistant in nature. The presence of MBL-producing bacteria in the community portend serious health risk because organisms producing MBL are notably resistant to carbapenems including imipenem and meropenem, which are antibiotics reserved for serious bacterial infections including those caused by bacteria that produce extended spectrum beta-lactamases $[1,9]$. On the other hand, bacteria that produce AmpC enzymes are remarkably resistant to the cephamycins including cefoxitin and cefotetan, which are second generation cephalosporins that are used for the treatment of bacterial-related infections [13,18,28-30]. Conclusively, the early and accurate detection of MBL- and AmpCproducing Enterobacteriaceae from abattoir and clinical samples is of utmost public health importance due to the multidrug resistant nature of these organisms. Our study shows that Klebsiella species and E. coli from abattoir sources produce MBL- and AmpC enzymes that allow them to be resistant to the antimicrobial onslaught of carbapenems and cephamycins respectively; and these organisms are multidrug resistant in nature. The rapid spread of resistance among bacteria may be attributed to the widespread and inappropriate use of antibiotics in animal husbandry and for other non-clinical purposes. Appropriate preventive measures are advocated to prevent the emergence of newer resistance mechanisms among bacteria species in non-clinical environments. We recommend proper detection of resistant bacteria from community samples, as well as the discouragement or stoppage of the use of antibiotic as growth promoting agents in animal husbandry and other agricultural practices.

\section{References}

1. Ejikeugwu C, Duru C, Eluu S, Oguejiofor B, Ezeador C, et al. (2017) Isolation and Phenotypic Detection of Metallo-Beta-Lactamase (MBL)-Producing Klebsiella Species from Cow Anal Swabs. Glob J Pharmaceu Sci 2: 1-5.

2. Shin HH, Cho SH (2013) Prevalence of Antimicrobial Resistance in Escherichia coli Strains Isolated from Fishery Workers. Osong Public Health Res Perspect 4: 72-75. [Crossref]

3. Yong D, Toleman MA, Giske CG, Cho HS, Sundman K, et al. (2009) Characterization of a New Metallo- $\beta$-Lactamase Gene, blaNDM-1, and a Novel Erythromycin Esterase Gene Carried on a Unique Genetic Structure in Klebsiella pneumoniae Sequence Type 14 from India. Antimicrob Agents Chemother 53: 5046-5054. [Crossref]

4. Ejikeugwu PC, Ugwu CM, Iroha IR, Eze P, Gugu TH (2014) Phenotypic Detection of Metallo- $\beta$-Lactamase Enzyme in Enugu, Southeast Nigeria. American Journal of Biological, Chemical and Pharmaceutical Science 2: 1-6.

5. Iyobe S, Hisakanu Y, Akio K, Ryoidi O, Hidero K, et al. (2001) Plasmid Encoded, Metallo-Beta-lactamases, conferring Resistance to carbapenems, especially meropenem. Antimicrob Agents Chemothe 45: 13-43.

6. Thompson KS (2010) Extended - spectrum $\beta$-Lactamase, AmpC, and Carbapenemase Issues. J Clin Microbiol 48:1019-1025.

7. Franco MR, Caiaffa-Filho HH, Burattini MN, Rossi F (2010) Metallo-betalactamases among imipenem-resistant Pseudomonas aeruginosa in a Brazilian University hospital. Clinics 65: 825-829.

8. Tortola MT, Lavilla S, Miro E, Gonzalez JJ, Larrosa N, et al. (2005) First Detection of a Carbapenem -Hydrolyzing Metalloenzyme in Two Enterobacteriaceae Isolates in Spain Antimicrob Agents Chemothe 49: 3492-3494.

9. Walsh TR, Toleman MA, Poirel L, Nordmann P (2005) Metallo-beta-lactamases: the quiet before the storm? Clin Microbiol Rev 18: 306-325. [Crossref]

10. Queenan AM, Bush K (2007) Carbapenemases: the versatile beta-lactamases. Clin Microbiol Rev 20: 440-458. [Crossref]
11. Cornaglia G, Giamarellou H, Rossolini GM (2011) Metallo- $\beta$-lactamases: a last frontier for $\beta$-lactams? Lancet Infect Dis 11: 381-393. [Crossref]

12. Caroff N, Espaze E, Gautreau D, Richet H, Reynaud A (2000) Analysis of the effects of -42 and -32 ampC promoter mutations in clinical isolates of Escherichia coli hyperproducing AmpC. J Antimicrob Chemother 45: 783-788. [Crossref]

13. Jacoby GA (2009) AmpC beta-lactamases. Clin Microbiol Rev 22: 161-182, Table of Contents. [Crossref]

14. Hanson ND, Sanders CC (1999) Regulation of inducible AmpC beta-lactamase expression among Enterobacteriaceae. Curr Pharm Des 5: 881-894. [Crossref]

15. Tan TY, Ng SY, Teo L, Koh Y, Teok CH (2008) Detection of plasmid-mediated AmpC in Escherichia coli, Klebsiella pneumoniae and Proteus mirabilis. J Clin Pathol 61: 642-644. [Crossref]

16. Clare F, Lisa L, Anton YP (2006) Phenotypic Detection of Carbapenem-Susceptible Metallo-Lactamase-Producing Gram-Negative Bacilli in the Clinical Laboratory. $J$ Clin Microbiol 44: 3139-3144. [Crossref]

17. Cheesbrough M (2002) Biochemical tests to identify bacteria. In: Laboratory practice in tropical countries. Cambridge Press, pp: 36-70.

18. Ejikeugwu PC, Edeh C, Iroha IR, Orji J, Eluu SU (2016) Antibiogram and Detection of Metallo-Beta-Lactamase (MBL) positive Escherichia coli isolates from abattoir. Nature and Science 14: 65-69.

19. Clinical Laboratory Standard Institute (CLSI) (2011) Performance standards for antimicrobial disk susceptibility test. Fifteenth informational supplement, CLSI document M100-S15, Wayne, USA.

20. Varaiya A, Kulkarni N, Kulkarni M, Bhalekar P, Dogra J (2008) Incidence of metallo beta lactamases producing Pseudomonas aeruginosa in ICU patients. Indian J Med Res 127: 398-402. [Crossref]

21. Jacoby GA, Munoz-Price LS (2005) The new beta-lactamases. N Engl J Med 352: 380391. [Crossref]

22. Akinjogunla OJ, Enabulele IO (2010) Virulence factors, plasmid profiling and curing analysis of multidrug resistant Staphylococcus aureus and coagulase negative Staphylococcus spp. isolated from patients with Acute Otitis Media. Journal of American Science 6: 1022-1033.

23. Adler H, Fenner L, Walter P, Hohler D, Schultheiss E, et al. (2008) Plasmid-mediated AmpC $\beta$-lactamases in Enterobacteriaceae lacking inducible chromosomal ampC genes: prevalence at a Swiss university hospital and occurrence of the different molecular types in Switzerland. Antimicrob. Chemother 61: 457-458.

24. Dahiya S, Singla P, Chaudhary U, Singh U (2015) Carbapenemasea: A Review. Int J Adv Heal Sci 2: 11-17.

25. Wegener HC (2003) Antibiotics in animal feed and their role in resistance development. Curr Opin Microbiol 6: 439-445. [Crossref]

26. Bashir D, Thokar MA, Fomda BA, Bashir G, Zahoor D, et al. (2011) Detection of metallo-beta-lactamase (MBL) producing Pseudomonas aeruginosa at a tertiary care hospital in Kashmir. Afr J Microbiol Res 5: 164-172.

27. Bora A, Sanjana R, Jha BK, Mahaseth SN, Pokharel K (2014) Incidence of metallo-betalactamase producing clinical isolates of Escherichia coli and Klebsiella pneumoniae in central Nepal. BMC Research Notes 7: 557.

28. Bush K, Jacoby GA, Medeiros AA (1995) A functional classification scheme for $\beta$-lactamases and its correlation with molecular structure. Antimicrob Agents Chemother 39: 1211-1233.

29. Paterson DL (2000) Recommendation for treatment of severe infections caused by Enterobacteriaceae producing extended-spectrum beta-lactamases (ESBLs). Clin Microbiol Infect 6: 460-463.

30. van Duin D, Bonomo RA (2016) Ceftazidime/Avibactam and Ceftolozane/Tazobactam Second-generation $\beta$-Lactam $/ \beta$-Lactamase Inhibitor Combinations. Clin Infect Dis 632: 234-241.

Copyright: (C2018 Ejikeugwu C. This is an open-access article distributed under the terms of the Creative Commons Attribution License, which permits unrestricted use, distribution, and reproduction in any medium, provided the original author and source are credited. 